\title{
Teoria e Prática da Notícia na Administraçũo Pública
}

ALAN VIGGIANO

Assessor de Imprensa na Universidade de Brasília

As figuras do "assessor de imprensa" e das "salas de imprensa", entre nós, são elementos recentemente saídos dos fornos e ainda não adquiriram os contornos nítidos que devem identificar o profissional dentro do quadro de especialização que se esboça nos nossos dias. É difícil e quase mesmo impossível identificar a data aproximada do aparecimento de uma e de outra figura.

Pode-se apenas lembrar que até o início da década de 60 - assessor de imprensa só existia ao lado do Presidente da República e dos Governadores de Estados mais importantes da Federação. Aos poucos, tìmidamente, os Estados mais modestos, um ou outro Tribunal Superior, os-Ministérios, uma ou outra Universidade ou autarquia foram enxergando a necessidade de manter uma pessoa ou equipe que facilitasse o trânsito da notícia da repartição para os órgãos de imprensa.

O quadro que hoje desfila ante nossos olhos, no setor da informação pública para a imprensa, caracteriza-se ainda pela extrema timidez na forma com que é tratado. Não há ocupante de cargo público que deixe de reconhecer a necessidade da existência de um homem ou de uma equipe para fazer chegar aos jornais, com eficiência e rapidez, as decisões tomadas em sua área. Mas são poucos os que conseguiram identificar a forma correta a ser utilizada para que isso se processe com o real proveito da comunicabilidade entre o administrador e o público.

1 - Muitas vêzes se comenta que êste ou aquêle administrador tem boa imagem. Isso não se faz por milagre, embora com essa assertiva estejamos a laborar no limiar do óbvio. Uma alta percentagem de casos como êsses pode ser atribuída ao 
soul da personalidade. Outro tanto, credite-se ao seu staff jornalístico.

Quando, porém, se encontra um administrador que, além de possuir o encanto e a vivacidade pessoal, consegue organizar em tôrno de si um grupo assessor de imprensa e uma instalação que permita levar suas decisões e as ações de sua repartição com eficiência e rapidez à imprensa diária, estará formado o círculo completo e daí surgirá a imagem que tão viva impressão causa.

Note-se aqui que não estamos falando de publicidade. Nem também de coquetéis, parties, vernissages. Tudo isso faz parte da montagem. Mas o que deve ser levado em conta mesmo é o trabalho rotineiro, de formiguinha: ir em busca da realização que está sendo elaborada nos - às vêzes - subterrâneos da repartição e levá-la a tempo e a hora, em forma de notícia ou de reportagem, até ao veículo, que a receberá com prazer.

2 - Três afirmações do trecho acima merecem reflexões: a primeira é aquela que diz em forma de notícia ou de reportagem. Ressalta do grifo o toque profissional da coisa. Qualquer chefe de reportagem ou secretário de redação que, de posse de um original, não lobrigue nas primeiras cinco linhas o conteúdo do que está lendo, o destinará fatalmente à cesta de papéis. Êste é um métier que não admite a perda de tempo.

A segunda das afirmações que merece reflexão é a de que - veículo a receberá com prazer. Essa assertiva poderá surpreender a muitos que conhecem a carranca característica dos chefes de redação. Mas deliciará aos poucos que já tiveram o privilégio de surpreender o sorriso secreto dêsses mafiosos diante de um texto perfeito, ao qual não terão nada a acrescentar, nada a criticar, nada a alterar. Posso imaginar a sua satisfação quando deparam com o dever cumprido e com a tranqüilidade de não ter que modificar uma linha sequer do escrito.

Certa vez, numa conferência, perguntaram a Lago Burnett, então editorialista do Jornal do Brasil, quais as qualidades requeridas para se escrever naquele jornal. Burnett disse que a resposta podia ser resumida em uma palavrinha que gastava apenas um quarto do número de letras necessárias para um título de uma coluna no Jornal do Brasil: bem.

A tarefa de aprender a escrever bem só é comparável ao trabalho de busca da simplicidade, proposta por Burnett aos que desejam escrever para jornal. "A sim- 
plicidade - diz êle - quando não é um dom pessoal - há pessoas que realmente se expressam de forma natural e espontânea - deve ser obtida artificialmente. Talvez isso possa parecer paradoxal. Mas é verdadeiro. Nem todos os bons artistas primitivistas são homens rudes. Muitos só conseguem mesmo chegar à absoluta depuração formal e ao completo despojamento conteudístico, após haver atingido um grau razoável de cultura. Daí fazem então a viagem de retôrno ao estado mais puro, o estágio das descobertas que todo artista persegue e que as crianças esbanjam".

Entre nós, escreve-se muito, e mal. Ganha-se em quantidade para perder-se em qualidade. Um poeta, conhecido por sua mordacidade, dizia-me, numa conversa sôbre concursos literários, que no Brasil devia ser instituído um prêmio bem valioso para a pessoa que provasse nunca haver escrito um poema. Despojado o comentário de seu possível exagêro, refletirá êle uma realidade bem visivel.

A tempo e a hora - Outra afirmação que merece a mais alta reflexão para aquêles que escolheram abraçar a peculiar, árdua, incompreendida, mas fascinante função de assessor de imprensa. A tempo e a hora. Essa expressão merece um parágrafo à parte.

Se o assessor de imprensa encaminha o material de qualquer maneira à redação dos jornais e julga que cumpriu o seu dever, está enganado. Um jornal é composto de diferentes partes, cada uma das quais fecha em diferentes dias e horas. O segundo caderno, por exemplo, geralmente é feito de manhã e fecha ao meio-dia. O assessor identificará aí a reportagem, a seção especializada, a crônica, a informação rotineira. Êle tem de saber a quem encaminhar as matérias de sua repartição.

Já o noticiário do dia vai chegando na parte da tarde e sendo selecionado por assunto e página, tendo o jornal um cronograma de fechamento que deixa por último a primeira e a terceira. A primeira página é um espelho onde se refletem os assuntos principais em miniatura, trazendo duas ou três fotos importantes.

Normalmente é fácil selecionar êsses assuntos de primeira página, nos agitados tempos atuais. Mas há dias em que a seara está tão fraca que o secretário tem de apelar para os cisnes do lago ou os lírios do campo. O assessor cuidadoso estará atento a essas oportunidades, com fotos de boa qualidade, textos leves 
e jornalísticos, que serão, em boa percentagem, aproveitados pelo veículo.

É quase impossivel identificar a percentagem do material de assessoria aproveitado imediatamente pelos veículos. Nos jornais da própria localidade, essa percentagem se aproxima de cem. Nos jornais de nivel nacional êsse percentual baixa muito, sem qualquer possibilidade de comprovação, é certo, porque a importância do problema não justifica uma pesquisa. Apenas uma avaliação superficial.

Mas, nada se perde completamente. Mesmo o material inaproveitado no momento fica a circular na redação e parte dêle será aproveitada lateralmente. Nesse sentido tenho dois depoimentos significativos a fazer. O representante de uma editôra de revistas nacionais afirma ser o material de assessoria utilizado, e com grande proveito, não como notícia, mas como informação para a feitura das pautas semanais e mensais.

O outro episódio é pitoresco: numa coluna diária de um grande jornal do país, dados veiculados dias antes pela assessoria a que me encontrava ligado foram manipulados de maneira a anular completamente o resultado do trabalho de assessoria. E sem sequer citar a fonte de onde vieram. Evidentemente isto envolve uma boa dose de pilantragem de que todos nós já fomos vítimas pelo menos uma vez.

Há ainda a considerar a existência de outros veículos, como o rádio e a televisão. A assessoria precisa estar a par dos horários dos noticiosos, para que o noticiário não chegue morto às estações. Além disso, deverá, se possível, preparar textos curtos especialmente para êsse tipo de veículo, boas fotos ou slides para televisão e, num grau maior de sofisticação, até mesmo pequenos filmes. $O$ aproveitamento do material de assessoria nas estações de rádio e televisão no Distrito Federal é bastante satisfatório.

Uma apreciação do assessoramento de imprensa na administração pública implica em abordagem tríplice, levando-se em conta os pontos de vista do administrador, do jornal e do assessor de imprensa. Êsses interêsses circulam livremente e só da conjugação dos três é que resultará um bom trabalho de divulgação.

I - O administrador público, nas suas relações com a imprensa, precisa compreender três pontos essenciais: a) sua avaliação do grau de interêsse que a notícia pode suscitar nem sempre coincide com a dos responsáveis pelo veículo; b) o espa- 
ço destinado a determinado tipo de matéria varia de dia para dia, conforme seja êsse dia "bom" ou "mau" para as notícias; c) jornal é emprêsa e, como tal, está sujeito a organização que envolve planejamentos, compromissos trabalhistas, etc.

Outro aspecto para o qual o administrador deve voltar as suas vistas é o da facilitação que deve propiciar aos manipuladores da notícia no serviço público, quer os seus, quer os dos jornais. As portas devem sempre estar abertas, na medida em que aconselharem os interêsses da segurança. Isso porque só o jornalista profissional está treinado para identificar o fato destinado a se tornar notícia nos dias seguintes. Uma providência interessante nesse setor é o aproveitamento de funcionários com experiência jornalística nas salas de imprensa. Isso representa um passo adiante nas facilidades de veiculação.

O jornalista Eduardo Pinto, subchefe de reportagem do Jornal do Brasil, desenvolveu queixumes, da mais pura procedência, sôbre as dificuldades de relacionamento dos repórteres com os homens públicos. (Cadernos de Jornalismo e Comunicação do Jornal do Brasil, no 24). É um depoimento realista e uma análise sincera do comportamento de homens e instituições diante da imprensa.

"Em quase todos os órgãos públicos - diz Eduardo Pinto - os jornalistas que nêles trabalham são mais funcionários subalternos, isolados pela desconfiança, do que técnicos da informação. Em alguns setores, já foram até substituídos por pessoal sem nenhuma experiência.

Em outros casos, os jornalistas empregados nas repartições públicas nem mesmo têm acesso aos chefes. Ao invés de, como seria de esperar, irem êles em busca da notícia, identificando-a onde ela estiver, para só então submeter aos seus superiores hierárquicos a conveniência da sua divulgação, estão quase sempre reduzidos à condição de reescrevedores de notas. Sua tarefa mais importante fica sendo a de dar - quando possível - forma jornalística às matérias que Ihes são impostas. Como os que as escolhem não têm conhecimento da técnica da informação, não é de espantar que o noticiário fornecido pelas salas de imprensa ao final do dia seja na maioria das vêzes de nenhum, interêsse. Sobram dedos nas mãos para contar as exceções."

Como se vê, a coisa, ao invés de melhorar está piorando. Quando uma repartição possui, na maioria dos casos, uma gama imensa de assuntos de interêsse público, à espera de especialistas que os venham desentocar, e que poderiam dar nova movimentação e interêsse às salas de imprensa, a dificuldade 
aumenta cada dia, porque os jornalistas do serviço público não dispõem de autonomia para movimentar-se nos meandros das repartições.

II - Os responsáveis pela edição do jornal são os grandes árbitros da notícia. Cabe a êles o ônus de escolher onde e quando serão postas as matérias. Essa escolha é feita em função da busca de um equilibrio entre os interêsses da emprêsa a que servem, do público e da administração.

III - O assessor de imprensa serve como ponte da notícia entre $o$ administrador e o jornal. A êle cabe conjugar os interêsses de ambos os lados, fazendo com que o aproveitamento do material destinado à imprensa tenha o percentual mais elevado possível. É sua tarefa também captar a notícia dentro da repartição a que serve, dar-lhe forma jornalística, estabelecer sua hierarquia de valor e encaminhá-la, tão acabada quanto possível, aos diferentes departamentos ou editorias dos veículos.

Do ponto de vista da captação, seu ângulo é inteiramente inverso ao do jornalista ordinário. Porque enquanto êsse busca a notícia, ao assessor compete levá-la. Daí porque o assessor precisa ter capacidades outras que vão além daquelas exigidas de um repórter comum, como as de conhecer o funcionamento interno das redações, a hierarquia e as diversas formas de notícia. Precisa, ainda, ter trânsito livre na burocracia da repartição, a fim de poder interceptar um assunto de interêsse público, que muitas vêzes dorme numa gaveta qualquer.

Há também o lado inverso. A vaidade é um traço vigoroso na personalidade humana. O mais desprendido e humilde dos sêres vibra com o aparecimento do seu nome no jornal. E o informante, ser humano que é, deseja ver logo na primeira página do dia seguinte a sua informação, quando muitas vêzes ela, mesmo sendo valiosa, como tôdas o são, só merecerá um pequeno tópico de coluna especializada.

Outro caso flagrante de incompreensão: omissão de nomes. Muitas vêzes a notícia sai faltando um nome, uma fonte, um detalhe, e a tempestade desaba sôbre o assessor de imprensa. E com êsse material que êle tem de trabalhar.

Ocorre, muitas vêzes, que não é uma pessoa ou repartição o objeto de divulgação através de assessoria de imprensa, mas uma instituição. É o caso das universidades. Nessa circunstância, a tarefa torna-se mais simples, porém trabalhosa.

Nos dias atuais, cresce o interêsse pelo trabalho dos jovens, justamente para compensar a divulgação que o comportamento de alguns grupos vem alcançando na imprensa sensacionalista. Numa instituição pioneira, como é a Universidade de 
Brasília, onde só estudantes existem mais de quatro mil espaIhados por um campus imenso, na primeira experiência de universidade integrada do País, chovem pedidos de revistas, jornais e outras publicações sôbre a atividade de alunos e professôres. O trabalho de assessoria é feito então mais no sentido de selecionar e preparar o material, cujo volume natural já é suficiente para dar uma movimentação especial à sala de imprensa.

Embora surpreendentemente escassa a bibliografia sôbre salas de imprensa, sabe-se de sua existência nos Estados Unidos desde após o término da guerra de 1914-1918, com ligeira ênfase nos períodos de govêrno de Franklin D. Roosevelt e implantação definitiva no advento da Segunda Guerra Mundial.

James Reston, em "Artilharia da Imprensa", dá o panorama das relações governamentais com a imprensa nos Estados Unidos e, embora não cite números, revela com detalhes o conteúdo dessas relações. Que, aliás, não difere fundamentalmente do relacionamento govêrno-imprensa em nosso meio. Cada jornal importante daquele país mantém o seu correspondente na Casa Branca, no Congresso e nos Tribunais superiores.

A sala de imprensa da Casa Branca é uma estrutura sólida, que não muda muito. Há os homens "da casa", que estão sempre condicionados ao sistema, e há os que ali vão de vez em quando, com missões especiais dos veículos. A maioria dêsses últimos casos são repórteres de revistas com missão de entrevistar o Presidente ou qualquer dos seus assessôres.

A "Sala" é ali também um mecanismo complexo. Mantém todo o serviço de uma repartição, conjugado com os sofisticados aparelhos de uma moderna redação, com telex, telefones, funcionários próprios, cantina, salas para os mais diversos tipos de trabalho dos jornalistas. O que muda sempre é a maneira de cada um dos Presidentes no seu relacionamento com os representantes dos jornais.

O livro de Reston, mercê do adestramento que o autor revela no trato das relações govêrno-imprensa, é um relato seguro, fluente e até mesmo bem-humorado da convivência de personalidades governamentais com repórteres, e dêsses com políticos, reis, rainhas, governantes, que fazem romarias a Washington, como capital do Ocidente. 
A sala de imprensa pode se revelar um punhal de dois gumes. Feita para informar, não raro se torna fonte de desinformação ou agência de contra-informação. Exemplo disso é o caso nazista. Goebbels montou na Alemanha a mais bem organizada, complexa e completa estrutura de informação já conhecida. Controlava todos os jornais, salas de imprensa e os meios de informação para o exterior tão dràsticamente, que o mundo só tomou conhecimento da derrocada econômica do Reich muito tempo depois que o povo de Berlim já a conhecia e sentia na própria carne.

O chefe da informação nazista descia mão tão drástica sôbre a informação que chegava ao ponto de escrever êle próprio editoriais para o órgão oficial do govêrno, o "Voelkischer Beobachter", e mais tarde no semanário "Das Reich". Basta dizer que, segundo nos informa Howard Smith, correspondente da UPI em Berlim, a economia alemã começou a esfacelar-se em 1941, mas a propaganda conseguiu escondê-la do mundo até 1945 , quando se decidiu a guerra.

O poder negativo das salas de imprensa é, porém, uma exceção. Cada dia que passa, novas emprêsas, instituições, repartições de govêrno, e organizações de todo tipo convencemse de sua utilidade, não só aquela utilidade imediata, de manter o público informado quando se dá um caso excepcional. Essa parte é apenas a que aparece, como num iceberg. O pedaço que fica escondido é três vêzes maior e mais importante do que é notado pelo público e constitui o underground de que se nutre a informação pública.

BIBLIOGRAFIA

"De Jornal em Jornal" - Lago Burnett, edição da Gráfica Record Editôra.

"Cadernos de Jornalismo e Comunicação", do Jornal do Brasil, $n$ ? 24, página 65 e seguintes.

"Interferência do mêdo na comunicação social", Eduardo Pinto.

"Artilharia da Imprensa" - James Reston, Editôra Laudes, tradução de Luís Orlando Carneiro - 1968.

"O último trem de Berlim" - Howard K. Smith, tradução de Antonio Accioly Netto - Emprêsa Gráfica "O Cruzeiro", 1943. 